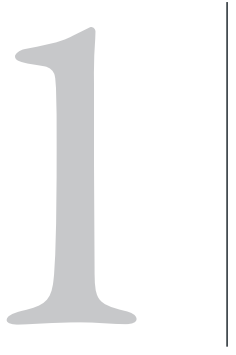

\title{
SUBNATIONAL ATOMIZATION AS A FACTOR OF INCREASING CORRUPTION IN VENEZUELA
}

\author{
LA FRAGMENTACIÓN MUNICIPAL \\ COMO FACTOR DE MAYOR \\ CORRUPCIÓN EN VENEZUELA
}

\section{Antonio Lecuna}

Recibido: $11 / 01 / 2018$

Aceptado: 26/06/2018

\section{A B S T R A C T}

The greater the number of subnational jurisdictions relative to the population and the greater the number of vertical tiers of government, the greater the incentives for corruption. The specific focus of the research is on the atomization of subnational governments and the creation of community councils as two factors of flawed political decentralization that are linked to increased corruption in Venezuela. The propositions are tested using fieldwork analysis on three subnational units of governance in Venezuela and multivariate statistical tests against a wide range of controls on 100 randomly selected countries.

K E Y W O R D S : Corruption, Venezuela, decentralization, subnational, atomization 


\section{R E S U M E N}

Cuanto mayor sea el número de jurisdicciones subnacionales en relación con la población y mayor sea el número de niveles verticales de gobierno, mayores serán los incentivos para la corrupción. El foco de estudio se centra en la atomización de los gobiernos subnacionales y en la creación de los consejos comunales como dos factores de descentralización política que están vinculados con el aumento de la corrupción en Venezuela. Siguiendo una estrategia de triangulación, las propuestas se sometieron a pruebas de análisis cualitativo en tres unidades de gobierno subnacional en Venezuela y a pruebas estadísticas multivariantes contra una amplia gama de controles en 100 países elegidos al azar.

P A L A B R A S C L A V E: Corrupción, Venezuela, descentralización, subnacional, atomización

\section{I N T R O D U C T I O N}

The fragmentation of subnational governments has been the trend in transitional and developing economies (Avellaneda and Gomes, 2015: 138). Indeed, a key principle of the umbrella term New Public Management (NPM) is "to decentralize implementation towards sub-national levels" (Saravia and Gomes, 2008: 494). Following Shleifer and Vishny (1993), Prud'homme (1995), Treisman (2002), Bardhan (2005), and Bardhan and Mookherjee (2006), this study specifically challenges the assumptions behind fragmentation theory. I use statistical evidence that draws upon fieldwork in a highly corrupt context to draw attention to two political decentralization factors that are associated with increased corruption: (1) the existence of a relatively excessive number of regional and local governments, or subnational atomization, and (2) the rise of an undemocratic third subnational government tier, such as community councils.

The findings are relevant because controlling corruption is a top priority of most policymakers worldwide (Nguyen et al., 2017). In addition, research regarding corruption in subnational public organizations remains sparse and inconclusive in the field of public administration (Beeri and Navot, 2013). Thus, any study that contributes to understanding the determinants of corruption at a subnational level of government is beneficial (Beeri and Navot, 2013). In particular, research that contributes to the perennial and important task of refining public policy instruments that will support development in South American countries (McCourt, 2008: 475).

In section 2 below, the hypotheses are introduced within the theoretical framework of NPM. The focus is on the relatively weak assumptions of 
fragmentation theory. In the statistical sections, I first define the data and then report the most significant results. Fieldwork information from three units of analysis is also used as evidence of increased corruption in Venezuela. Before concluding, the paper discusses implications of the research by formulating viable government policies with regard to the current public policy reform process in Venezuela and elsewhere.

\section{CONTEXTUAL BACKGROUND: \\ CHAVISMO IN VENEZUELA}

The chavismo revolution transformed political institutions from a subsidized coalition that nearly privatized the oil industry to a radical leftist populism that has polarized society to the brink of civil war. Far from a mere historical regression to an era dominated by charismatic populist figures, chavismo represents a new and genuinely radical mass movement (Wood, 2009). Chavismo captivated the poor and the excluded with the Bolivarian ideology, inspired mainly by the writings and actions of: Simón Bolívar, the hero of independence; Ezequiel Zamora, the civil war leader; and Simón Rodríguez, Bolívar's tutor (Sanoja, 2009). Bolívar contributed to nationalism and to independence from imperial dominance, Zamora fought for social justice and the unity of peasants with the army, and Rodríguez led the drive for educating the masses and championed the search for a unique Venezuelan identity (Lecuna, 2013).

To some, Chávez was a Marxist-communist totalitarian with no intention of stepping down from power or of releasing institutional control over the oilrich revenues of Venezuela. Referred to as Castro's successor, Chávez was also a charismatic leader, a crafty politician, and a ranting populist (Sylvia and Danopoulos, 2003). To others, however, the godlike presence of Chávez represented the only hope to the desperate poor. Chávez seemed to rise as the last champion of a left that refuses to die in Latin America.

The left in Latin America is composed of three general ideologies: liberal republican, grass-roots democracy, and populism (Panizza, 2005). Although chavismo incorporates elements of the three traditions, radical populism has flourished with particular significance in Venezuela. The populist tradition emphasizes the notion of popular sovereignty, in which the desires of the people have primacy over the rights of the individual (Canovan, 1999). Popular sovereignty includes mechanisms for direct political participation (e.g., community councils) and opposes pacts and political negotiations (e.g., the Punto Fijo pact). 
Therefore, when judged in light of the populist tradition, chavistas fares much better (Ellner, 2010). However, when judged in light of the liberal republican tradition, which stresses the importance of citizens' rights and duties by strictly enforcing an independent rule of law, the two-decade long chavismo administration has failed miserably. This failure is exemplified by the increasing polarization of the political landscape and by the resulting institutional deficiencies that have inhibited the community councils, cooperatives, and educational missions underpinning the Bolivarian ideology (Ellner, 2011).

The increasing institutional weaknesses in Venezuela represents the most relevant consequence of the two-decade long Chavista administration. Lin and Nugent (1995: 2306-07) broadly define institutions as "a set of humanly devised behavioural rules that govern and shape the interactions of human beings, in part by helping them to form expectations of what other people will do." North (1990) adds that institutions consist of both informal constraints (sanctions, taboos, customs, traditions, and codes of conduct) and formal rules (constitutions, laws, property rights). Following Arshed et al. (2014), this study recognizes the government as the formal institution.

\section{H Y P O T H S E D E VEL O P M E T}

Corruption is defined here as the misuse of public power for private gain. This is the most accepted definition of political corruption (Beeri and Navot, 2013: 713). Anti-corruption organizations, including Transparency International (TI), have widely used this working definition. Decentralization, in turn, is commonly defined as the process of devolving powers to regional and local governments by shifting the structure of accountability from the national level to the subnational level (Tiebout, 1956; Burki et al., 1999). Decentralization has historically been associated with encouraging government responsiveness (Oates, 1972) and controlling corruption (Huther and Shah, 1998; de Mello and Barenstein, 2001; Fisman and Gatti, 2002a; 2002b)².

Dating back to Tiebout's (1956) seminal work, the majority of research has exaggerated the theoretical merits of fragmentation theory. This exaggeration is explained mainly by the subnational competition assumption (Brennan and Buchanan, 1980). Beeri and Navot (2013: 718) warn, however, that 
competition between subnational governments is a "double-edged sword" because the subnational competition assumption takes for granted the proposition that government responsibilities are perfectly defined ${ }^{3}$.

In an already highly corrupt institutional environment such as Venezuela's, responsibilities are not clearly defined. In fact, some may argue that government responsibilities are purposely blurred to generate corruption incentives. According to Fisman and Gatti (2002a: 328), if decentralization creates multiple units of government, it may actually weaken accountability because voters have more difficulty attributing blame for failures. For example, subnational leadership tends to attribute corruption to external (i.e., global or national) factors, such as changes in national goals, priorities, or policies; reduced financial support; and high consumer expectations (Beeri and Navot, 2013: 717). Conversely, the central government will tend to attribute corruption to regional and local government factors, such as poor leadership, mismanagement, and internal conflicts (Boyne, 2006). Whatever the case might be, the end result is that as a voter, it is practically impossible to observe and compare the performance of officials or bureaucrats across subnational jurisdictions.

In addition to the subnational competition assumption, fragmentation theory also assumes that information is relatively more accessible to local officials (Inman and Rubinfeld, 1996; 1997). This assumption is also unsustainable for two reasons. First, national governments' economies of scale are likely to produce institutional advantages for obtaining and comprehending all types of information (Prud'homme, 1995). Second, the majority of national-level agents are residents of subnational governments; thus, they have exactly the same capacities as local officials to perceive and understand heterogeneous regional and local information (Bardhan and Mookherjee, 2006). Moreover, fragmentation theory is further based on the assumption that subnational governments are divided and organized according to the needs and preferences of their constituents. In reality, developing countries such as the case of Venezuela are divided mainly based on their potential income rather than on qualitative differences, including ethno-linguistic or geographical differences (Prud'homme, 1995).

\subsection{POLITICAL DECENTRALIZATION INCREASES CORRUPTION}

NPM classical fragmentation theory encourages a push away from large centralized governments toward more decentralized and manageable units

3. In line with the subnational competition assumption, one of the doctrinal components of NPM related to accountability also assumes the "clear assignment of responsibility for action" (Hood, 1991: 4). 
(Bryson et al., 2014: 447). However, since the relatively weak assumptions of fragmentation theory generally do not apply to the developing corrupt reality, I therefore specify the following two hypotheses related to political decentralization: political decentralization (horizontal and vertical) has direct and independent effects on corruption, as measured by the perceptions of the degree of corruption-i.e., (H1) corruption is positively affected by the atomization of subnational governments, and (H2) corruption is positively affected by the increased number of vertical tiers of government.

The statistical results should further support the "less conventional" arguments that larger subnational governments (in terms of population) tend to be more efficient (Avellaneda and Gomes, 2015: 138) and tend to enjoy better transparency (Albalate del Sola, 2013), in comparison to smaller subnational governments. Similarly, increasing the number of vertical tiers of government could lead to greater corruption because the total number of bribes tends to be greater with a greater number of vertical tiers of governance with independent rights (Shleifer and Vishny, 1993).

\subsection{FISCAL DECENTRALIZATION DECREASES CORRUPTION}

Though the literature on fiscal federalism is vast, most studies define fiscal decentralization based on the expenditure side and do not include the devolution-of-revenue effect. Therefore, as a contribution to the literature, I hypothesize that there is a direct and positive relationship between increasing corruption and one specific revenue-based measure of fiscal decentralization-i.e., (H3) countries with greater subnational powers to collect taxes tend to have less corruption ${ }^{4}$.

The expected results should support the argument that a lack of subnational revenue autonomy restricts public budgets and creates dependency on central finances, which in turn distorts the optimal efficiency equilibrium between marginal costs and marginal profits that is achieved through a gradual process of adjusting expenditures to benefits at the margin (Arze and Martínez Vázquez, 2004). In other words, a lack of revenue autonomy should disrupt the government-enhancing effects that result from a balance between effort and performance and should undermine a key mechanism for controlling corruption (Fisman and Gatti, 2002b).

4. Scholars tend to agree regarding the hypothesis that fiscal decentralization decreases corruption (Huther and Shah, 1998; De Mello and Barenstein, 2001; Fisman and Gatti, 2002b; Dincer et al., 2010), mainly because bureaucrats in a fiscally decentralized economy have fewer incentives to engage in rent-seeking behavior (Arikan, 2004: 192). 


\section{SA M P L A N D D E F I I T I O N O F T H D A T A}

The statistical sample is a random sample of 100 countries, as shown in Table A1. The sample selection is evenly distributed using the Human Development Index (HDI) value developed by the United Nations Development Program (UNDP) among 24 countries that rank very high on the HDI, 24 countries that rank high, 24 countries that rank medium, and 28 countries that rank low. The distribution of the countries is almost identical to the HDI world population of 187 countries.

\subsection{DEPENDENT VARIABLE}

The information on corruption is sourced from the 2009 Corruption Perception Index (CPI) published by the reliable anti-corruption organization TI. This index measures perceptions of the degree of corruption-not the actual level-as observed by business people, academics, and risk analysts. Scores range from 0 to 10 , with higher values indicating better ratings. The CPI is the best-known index available (Tanzi, 1998: 577). The external validity of the dependent variable is tested using a bivariate correlation analysis between the CPI and the control of corruption indicator included in the World Bank's Worldwide Governance Indicators. The World's Bank definition of corruption is similar to the definition used by TI ("the abuse of entrusted power for private gain"): corruption reflects perceptions of the extent to which public power is exercised for private gain, including both petty and grand forms of corruption as well as capture of the state by elites and private interests. As expected and confirmed by tests in many other studies, the correlation value between these two variables is very high (over 0.80 ), indicating the high external validity of this study's dependent variable.

\subsection{INDEPENDENT VARIABLES}

Subnational atomization, or population per regional government, is the total population of the country divided by the total number of regional governments (first-tier subnational level). This variable is logged to avoid skewness. In line with the first hypothesis, the expected direction is positive, indicating that countries divided into fewer regional units (i.e., more population per region), on average, have higher corruption scores. Therefore, the greater the number of subnational governments, the greater the probability of corruption. The information for the total population is sourced from the 2008 Population Division of the United Nations Department of Economic and Social Affairs, and the information for the total number of regional governments is sourced from the Inter- 
national Organization for Standardization (ISO) 3166 subdivision codes for $2008^{5}$.

To the best of my knowledge, the proxy I propose for subnational atomization (measured by dividing a country's total population by its total number of first-tier subnational governments) is relatively new because most scholars do not consider population to be a significant factor in mobility. This interpretation apparently arises because most scholars use "average area of first-tier unit" as a proxy for the atomization of subnational governments given that the costs of moving are likely to increase with the geographic size of the subnational unit and not with the average population per jurisdiction (Treisman, 2002). In terms of geographic distances, it is much easier to move freely to a nearby state (Brennan and Buchanan, 1980).

Government tiers are the total number of subnational vertical levels (i.e., tiers) of government. There are two typical political subdivisions of countries: regional (i.e., state) and local (i.e., municipality). In line with the second hypothesis, the expected direction is negative, indicating that countries with more vertical tiers, on average, have higher corruption scores. That is, the greater the number of vertical tiers of government, the greater the probability of corruption. The source of information for government tiers is the ISO 3166 subdivision codes for the year 2008.

Revenue autonomy is the 2008 regional government revenue as a percentage of total revenue. Expenditure autonomy is the 2008 regional government expenditure as a percentage of total expenditure. The source of information for revenue autonomy is the International Monetary Fund's 2008 Government Finance Statistics Yearbook (IMF). The expected signs are positive (Fisman and Gatti, 2002a).

\subsection{CONTROL VARIABLES}

Drawing upon corruption and decentralization theory, seven controls are used, which are described in Table 1. Table A2 reports the descriptive statistics of all variables, whereas Table A3 displays the correlation matrix of the variables:

5. When a country is divided into two or more tiers, the information on the first tier will be used as the denominator. The information on regional governments is used instead of local governments because it is considerably more accessible and consistent. 
TABLE 1.

DESCRIPTION OF CONTROL VARIABLES

\begin{tabular}{|c|c|c|c|c|}
\hline VARIABLE & DEFINITION & SOURCE & SCALE & EXPECTED SIGN \\
\hline DEMOCRACY & $\begin{array}{l}\text { Focuses on electoral proces- } \\
\text { ses, participation, govern- } \\
\text { ment functioning, civil liber- } \\
\text { ties, and political culture. }\end{array}$ & $\begin{array}{l}2008 \text { Economist } \\
\text { Intelligence Unit } \\
\text { Democracy Index. }\end{array}$ & $\begin{array}{l}\text { From } 0 \text { to } 10, \text { with } \\
\text { higher values } \\
\text { indicating better } \\
\text { ratings. }\end{array}$ & $\begin{array}{l}\text { Positive } \\
\text { (Treisman, 2000). }\end{array}$ \\
\hline INCOME & $\begin{array}{l}2008 \text { gross domestic product } \\
\text { (GDP) per capita at purchasing } \\
\text { power parity (PPP), measured } \\
\text { in US dollars. }\end{array}$ & $\begin{array}{l}\text { IMF World } \\
\text { Economic Outlook } \\
\text { Database. }\end{array}$ & $\begin{array}{l}\text { Logs are used to } \\
\text { avoid extremely } \\
\text { high and low } \\
\text { observations. }\end{array}$ & $\begin{array}{l}\text { Positive } \\
\text { (Mauro, 1995). }\end{array}$ \\
\hline EDUCATION & $\begin{array}{l}\text { Adult literacy rates (weighted } \\
\text { two-thirds) and gross school } \\
\text { enrolment ratio (weighted } \\
\text { one-third). }\end{array}$ & $\begin{array}{l}2008 \text { United } \\
\text { Nations Education } \\
\text { Index }\end{array}$ & $\begin{array}{l}\text { From } 0 \text { to 1, with } \\
\text { higher values } \\
\text { indicating better } \\
\text { ratings. }\end{array}$ & $\begin{array}{l}\text { Positive } \\
\text { (Ades and Di Tella, } \\
\text { 1997). }\end{array}$ \\
\hline INEQUALITY & $\begin{array}{l}\text { Statistical dispersion of inco- } \\
\text { me inequality (i.e., the degree } \\
\text { of inequality in the distri- } \\
\text { bution of family income in a } \\
\text { country). }\end{array}$ & $\begin{array}{l}2008 \text { CIA World } \\
\text { Factbook Gini } \\
\text { inequality } \\
\text { coefficient. }\end{array}$ & $\begin{array}{l}\text { From } 0 \text { to 1, with } \\
\text { lower values } \\
\text { indicating better } \\
\text { ratings. }\end{array}$ & $\begin{array}{l}\text { Negative } \\
\text { (Gupta et al., 1998). }\end{array}$ \\
\hline PRESS & $\begin{array}{l}\text { Measures freedom of journa- } \\
\text { lism and the efforts made by } \\
\text { governments to see that press } \\
\text { freedom is respected. }\end{array}$ & $\begin{array}{l}2008 \text { Reporters } \\
\text { Without Borders } \\
\text { World Press } \\
\text { Freedom Index. }\end{array}$ & $\begin{array}{l}\text { Lower scores } \\
\text { correspond to } \\
\text { better ratings. }\end{array}$ & $\begin{array}{l}\text { Negative } \\
\text { (Brunetti and } \\
\text { Weder, 1998). }\end{array}$ \\
\hline TRADE & $\begin{array}{l}\text { Focuses on the absence of } \\
\text { tariff and non-tariff barriers } \\
\text { that affect the import and } \\
\text { export of goods and services. }\end{array}$ & $\begin{array}{l}2008 \text { Heritage } \\
\text { Foundation and } \\
\text { the WSJ Trade } \\
\text { Freedom Index. }\end{array}$ & $\begin{array}{l}\text { From } 0 \text { to } 100 \text {, } \\
\text { with higher values } \\
\text { indicating better } \\
\text { ratings. }\end{array}$ & $\begin{array}{l}\text { Positive } \\
\text { (Ades and Di Tella, } \\
\text { 1996). }\end{array}$ \\
\hline PROTESTANT & $\begin{array}{l}\text { Protestant religion in a coun- } \\
\text { try during } 2004 \text { (Evangelical, } \\
\text { Quaker, Assembly of God, An- } \\
\text { glican, Baptist, etc.) }\end{array}$ & $\begin{array}{l}\text { U.S. State } \\
\text { Department } \\
\text { International } \\
\text { Religious Report. }\end{array}$ & $\begin{array}{l}\% \text { of the population } \\
\text { that practices } \\
\text { Protestantism. }\end{array}$ & $\begin{array}{l}\text { Positive } \\
\text { (Treisman, 2002). }\end{array}$ \\
\hline
\end{tabular}

\section{S I G N I F I C A N T S T A T I S T I C A L R E S U L T S}

This section briefly tests the four hypothesized measures of decentralization as potential factors of corruption: the atomization of subnational governments, the total number of vertical tiers of subnational governments (i.e., community councils), and a lack of revenue and expenditure autonomy. Given the cross-sectional nature of the dataset, including the depen- 
dent and independent variables, the following specifications are estimated using ordinary least squares (OLS) estimation with White-Huber standard errors to correct for heteroscedasticity.

As predicted by the underlying theory, the first column of Table 2 (i.e., control estimators) implies that authoritarian regimes are significantly more corrupt, mainly because democracy improves economic outcomes (Besley and Burgess, 2002) and fosters participation in a generalized interpretation of the rule of law (Bardhan, 2005). The null hypothesis that democracy is not related to corruption is clearly rejected because the computed t-value of 3.26 exceeds the one-tailed critical t-value of 3.19 at the $0.1 \%$ level of significance with 86 degrees of freedom. I use a one-tailed test here instead of a two-tailed test because the expected and actual democracy coefficient of the corruption function is strongly positive. In light of Venezuela's marked democratic erosion in recent years (Seawright, 2012: 152; Lecuna, 2013), the significant estimator of democracy partly explains high corruption.

TABLE 2.

\section{THE DETERMINANTS OF CORRUPTION, INCLUDING FLAWED DECENTRALIZATION (OLS CROSS-COUNTRY ESTIMATES)}

\begin{tabular}{|c|c|c|c|}
\hline $\begin{array}{l}\text { DEPENDENT VARIABLE: } \\
\text { CORRUPTION }\end{array}$ & $\begin{array}{c}\text { (I) } \\
\text { CONTROL ESTIMATORS }\end{array}$ & $\begin{array}{c}\text { (II) } \\
\text { BASIC EFFECT }\end{array}$ & $\begin{array}{c}\text { (III) } \\
\text { FISCAL DECENTRALIZATION }\end{array}$ \\
\hline Democracy & $\begin{array}{l}0.34^{* * *} \\
(3.26)\end{array}$ & $\begin{array}{l}0.29 * * * \\
(2.97)\end{array}$ & $\begin{array}{c}0.27^{*} \\
(1.70)\end{array}$ \\
\hline Income & $\begin{array}{l}2.20^{* * *} \\
(5.20)\end{array}$ & $\begin{array}{l}1.81^{* * *} \\
(4.62)\end{array}$ & $\begin{array}{l}2.10^{* * *} \\
(3.07)\end{array}$ \\
\hline Education & $\begin{array}{l}-3.07^{* * *} \\
(-2.79)\end{array}$ & $\begin{array}{l}-2.44^{* * *} \\
(-2.39)\end{array}$ & $\begin{array}{l}-3.16^{* *} \\
(-2.03)\end{array}$ \\
\hline Inequality & $\begin{array}{l}-0.04^{* * *} \\
(-2.82)\end{array}$ & $\begin{array}{l}-0.04^{* * *} \\
(-3.26)\end{array}$ & $\begin{array}{c}-0.04^{* * *} \\
(-2.54)\end{array}$ \\
\hline Press & $\begin{array}{l}1.00 \\
(0.04)\end{array}$ & $\begin{array}{l}-0.01 \\
(-0.95)\end{array}$ & $\begin{array}{l}-0.01 \\
(-1.00)\end{array}$ \\
\hline Trade & $\begin{array}{l}0.01 \\
(-0.04)\end{array}$ & $\begin{array}{l}0.01 \\
(0.97)\end{array}$ & $\begin{array}{l}0.03 \\
(0.97)\end{array}$ \\
\hline Protestant & $(3.20)^{2.19^{* * *}}$ & $(3.20)^{* * *}$ & $\begin{array}{l}1.93^{* *} \\
(2.46)\end{array}$ \\
\hline Subnational Atomization & & $\begin{array}{l}1.30^{* * * *} \\
(4.65)\end{array}$ & $\begin{array}{l}1.33^{* * *} \\
(3.22)\end{array}$ \\
\hline Government Tiers & & $\begin{array}{l}-0.32^{* *} \\
(-2.37)\end{array}$ & $\begin{array}{l}-0.40^{* *} \\
(-2.25)\end{array}$ \\
\hline Revenue Autonomy & & & $\begin{array}{l}1.07 \\
(0.35)\end{array}$ \\
\hline Expenditure Autonomy & & & $\begin{array}{l}-0.80 \\
(-0.26)\end{array}$ \\
\hline Observations & 94 & 94 & 63 \\
\hline F-value & 32 & 33 & 20 \\
\hline Adjusted $R$-squared & $70 \%$ & $76 \%$ & $77 \%$ \\
\hline
\end{tabular}

Notes: t-statistics are in parentheses. Standard errors are corrected for heteroscedasticity. In all cases, the computed f-values clearly exceed the critical f-values at 1\%; hence, the null hypothesis that the collective impact of all explanatory variables is simultaneously equal to 0 is rejected. Endogeneity is alleviated by lagging predictor variables one year (except Protestant).

Significance: ${ }^{*} p<10 \%$; ${ }^{*} p<5 \%$; ${ }^{* *} p<1 \%$. 
Income is also highly significant, as the p-value of obtaining a t-value for this coefficient of as much as approximately 5 is close to zero. However, the size of the slope coefficient is only marginal. That is, if income increases by $1 \%$, on average, the forecasted corruption score will improve by only 0.02 points. In other words, an increase in GDP per capita at PPP of one dollar would improve the forecasted mean CPI score only slightly, by 0.000104 points (holding other variables constant). Using linear estimates, on average, if GDP per capita almost doubled in Venezuela and increased by approximately US $\$ 10,000$, this would imply only a one-point increase in the corruption rating (scale of 0 to 10).

The second column of Table 2 (i.e., basic effect) strongly supports two potential factors of corruption. This finding arises because subnational atomization (H1) and subnational tiers (H2) enter the regression with strong coefficients reinforced with significant p-values. Overall, the adjusted multiple coefficient of determination improves by six percentage points, to $76 \%$, which is a relatively high value, and the test of overall significance becomes more consistent when the proposed variables enter the regression. The slope of subnational atomization implies that if population per regional government increases by $1 \%$ on average, then the forecasted corruption score will improve by 0.013 points. This correlation is highly significant because the null hypothesis that the true slope coefficient is 0 is not rejected on only 12 occasions in one million.

Furthermore, as expected, subnational tiers enter the regression model with a strong negative sign reinforced with a significance level of less than $5 \%$, implying that the greater the quantity of subnational levels of government, the lower the CPI score. The third column (i.e., fiscal decentralization) of Table 2 comes as a surprise. In contrast to the hypothesis that the power to tax (H3) is associated with decreased levels of corruption, the main measure of fiscal decentralization-revenue autonomy-enters the regression showing an insignificant correlation with the dependent variable, corruption. It is important to note that subnational atomization and government tiers do not lose significance and strength with the inclusion of the fiscal decentralization variables ${ }^{6}$.

6. The strong explanatory power of Protestant, the direction of education, and the insignificant coefficients of press and trade require further analysis, which is beyond the scope of this paper. 


\section{F I E L D W O R K D A T A}

To further support the development of the hypotheses, fieldwork data collection was conducted on three different units of analysis in the highly corrupt context of Venezuela: two ideologically opposed municipalities (Gaspar-Marcano and Naguanagua) and a community council in the state of Nueva Esparta ${ }^{7}$. The research process separated and treated these locations as three independent sub-cases of the general case study on decentralization and corruption in Venezuela. The three sub-cases are reasonable and comparable units of observation because they resemble the political landscape in Venezuela and behave similarly with regard to the consequences of flawed decentralization. Particular emphasis is placed on key informants from the two municipalities because local governments are the first and most important locus of interaction between citizens and the public sector (Holden et al., 2003).

\subsection{SUBNATIONAL ATOMIZATION}

In Venezuela, the mean population of the 335 municipalities is approximately 88,000 inhabitants. One municipality (Libertador) has a population of two million, and another municipality (Maracaibo) has one-and-a-half million inhabitants. Three municipalities (Barquisimeto, Valencia, and Ciudad Guyana) have populations of approximately 800,000 inhabitants each. Five municipalities have populations of approximately 500,000 inhabitants each. However, the remaining 325 municipalities are, on average, remarkably poor and have relatively small populations. In fact, several municipalities have populations of fewer than 5,000 inhabitants, and some have fewer than 2,000 inhabitants (Maroa, Río Negro, and Simón Rodríguez). In accordance with H1, Naguanagua Mayor Alejandro Feo nicely summarized the effect of subnational atomization as a potential factor in corruption in one of my interviews with him: "Only a few municipalities are rich and powerful, but the remaining majority are relatively poor, geographically small, newly created, and scarcely populated. This generates disadvantages in economies of scale, which in turn causes elected officials and public

7. The municipality of Gaspar-Marcano has a predominately poor total population of 32,000 , most of whom are dedicated to traditional fishing. Naguanagua, with a total population of 168,000 , consists primarily of rich neighborhoods in the industrial state of Carabobo.

8. An entry interview using a semi-structured format was conducted with the mayor of each municipality at the time of the study: Alejandro Feo (opposition municipality mayor of Naguanagua) and Ibrain Velásquez (chavista municipality mayor of Gaspar-Marcano). After the initial interviews with the elites, semi-structured interviews with lower-level staff were conducted. The core line of questioning was similar for elites and staff respondents. Interviews generally consisted of two key open-ended questions and four relevant follow-up questions. However, following the method of inductive research, these questions were supplemented with others that seemed fruitful to pursue during the interview process 
personnel of relatively small jurisdictions to be more vulnerable to capture by corrupt private elites."

While subnational amalgamation is the norm in countries such as Austria, Japan, Denmark, Finland, and the United States (Avellaneda and Gomes, 2015: 137), Latin America is suffering from atomization. From 1994 to 2010, local governments in Latin America increased from 13,951 to 16,204. The greatest increases occurred in Argentina and Venezuela (Avellaneda and Gomes, 2015: 149). Subnational atomization, as defined here, refers to an excessive number of regional and local governments in relatively poor and scarcely populated small territories. Arze and Martínez Vázquez (2004: 624) define atomization as the concentration of the population in a reduced number of subnational units and, in general, a lack of homogeneity in the distribution of jurisdictions relative to the population.

The two most relevant arguments that reciprocally link flawed decentralization and corruption through the atomization of subnational governments were as follows: decentralization (1) generates disadvantages in economies of scale and (2) increases the waste of public resources resulting from duplication. These two arguments accounted for more than half of the total responses to the question "Why does subnational atomization increase corruption ${ }^{9 \prime \prime}$

\subsection{CREATION OF COMMUNITY COUNCILS}

Community councils in Venezuela introduce a third subnational tier of government below the regional (i.e., state) and local (i.e., municipality) levels. Community councils are unelected bottom-up institutions in which small groups of people (usually 200 to 400 families in the cities and 100 to 200 families in rural areas) can have a united voice and obtain direct financial access to public decisions and resources. In general, encouraging decentralized decision making with community participation regarding public affairs through "the creation of new locally based forms of political representation in which elected community and communal institutions will be allocated state revenues rather than the corrupt, patronage-infested municipal and state governments" is a relevant issue that requires more attention (Petras, 2007: 2). According to one respondent, "New forms of political participation had to be created to bypass an inefficient bureaucracy and complete tasks once and for all."

9. One relevant limitation of this exercise is that I found no significant patterns worth reporting after probing deeper with questions such as "How could the disadvantages in the economies of scale cause corruption?" 
In agreement with $\mathrm{H} 2$, the problem with community councils is that instead of reaping the theoretical benefits, the councils may be increasing the following three incentives that drive corruption. Community councils weaken subnational institutions by introducing a deconcentrated tier of government that is subject to the discretion of an increasingly powerful national government. Furthermore, the creation of a dependent new tier of government encourages collusion between agencies in the vertical bureaucratic hierarchy and overgrazing by different autonomous governments that compete to extract bribes from the same economic actors. Finally, local government officials are simply not interested in sharing their political power and financial resources with local people. Approximately two-thirds of the responses to a question about corruption in community councils involved some combination of these three arguments.

\subsection{LACK OF REVENUE AUTONOMY}

Subnational governments in Venezuela have assumed greater responsibilities that require the expenditure of funds, but they have experienced very little financial autonomy, which is in line with H3. Most expenditures are still financed by constitutional funds and transfers from the national administration. This situation, in turn, restricts subnational public budgets and creates dependency on central finances, which increases the incentives for corruption. Fisman and Gatti (2002a: 329) explain this phenomenon very well: "Fiscal decentralization, particularly to the extent that devolution of revenue raising and expenditure power corrects vertical fiscal imbalances across levels of government, is often quoted as an important ingredient for accountability and, ultimately, good governance."

In Latin America, only a small number of local governments in Brazil, Chile, Mexico, and Peru can raise revenues through property taxes and service fees (Andersson and van Laerhoven, 2007). The general precedent throughout the region has historically been that municipal administrations depend heavily on central government transfers. The units analyzed in Venezuela share a problem typical in corrupt countries that reflects a lack of agreement between the national government and subnational jurisdictions regarding objectives and goals for spending policies, priorities, and resource availability. Indeed, according to most informants, the allocation formulas discourage local fiscal efforts since transfers are negotiable case by case instead of contract based and are not stable in time nor transparent. 


\section{P R A C T I C A L I M P L I C A T I O N S}

The first recommended policy is to decrease the number of subnational governments by consolidating poor and unpopulated units into governance organizations that would be more accountable. In other words, if the population per first-tier subnational government in Venezuela suddenly doubles, ideally through the consolidation of regional units from 24 to approximately 12 , the corruption score will improve 1.3 points assuming all other factors affecting corruption are held constant. This scenario suggests an increase of 70 places, from number 165 to number 95, in the CPI world corruption rankings. Similarly, if Venezuela were to eliminate the newly created community councils and return to the traditional subnational division of regional (i.e., state) and local (i.e., municipality) governments, its forecasted mean corruption score would improve from 1.9 to approximately 2.2.

In Venezuela, the first-tier division of government could ideally be organized into nine administrative regions corresponding to climatic and cultural backgrounds instead of today's structure of 23 states plus the capital district. Fortunately, the road to decreasing the number of subnational governments was paved more than four decades ago with a 1969 decree for regionalization that institutionalized a process of regional development, including dividing Venezuela into nine hypothetical regions. This decree has never been put into effect.

In parallel to decreasing the number of subnational governments, and in accordance with Arze and Martínez Vázquez (2004: 655), a straightforward government policy that could indirectly control corruption would be to empower the newly consolidated regional and local units to change at least one important tax, such as sales or property tax rates. Although the statistical tests do not confirm subnational revenue autonomy as a significant explanatory factor for corruption, empowering subnational governments to change sales or property tax rates in Venezuela should be sufficient to correct vertical fiscal imbalances and to encourage institutional innovations, such as income tax initiatives. 


\section{C O N C L U S I O N S}

Following Enikolopov and Zhuravskaya (2007), Fan et al., (2009), and Lecuna (2012), the paper aims to draw attention to the ostensible link between political decentralization and corruption. Two hypotheses: corruption is partly explained by subnational atomization (i.e., newly created regional and local units of government in relatively poor and scarcely populated small territories) and by new vertical tiers of governments (i.e., the creation of community councils in Venezuela). As a rule of thumb, the greater the number of vertical and horizontal subnational units of government, the greater the risk that the rents of office will be overgrazed because the number of public sector employees with pockets to fill increases. de Graaf and Huberts (2008) and Avellaneda and Gomes (2015: 139) add that the smallest subnational governments not only encourage corrupt enduring relationships, which are an important motive for corruption, but also exhibit inefficiency and transparency problems because they lack economies of scale.

A imitation of the study is that, even though the case of Venezuela poses interesting issues because of the broad political changes that have occurred there in recent years, Venezuela is only one example of a widespread phenomenon that concerns the interaction between corruption and decentralization. As Caiden and Sundaram (2004: 374) note regarding their use of the case of India, "What works in one place may well be applicable elsewhere but usually things are not so simple. There may be similarities, but usually there are just too many differences. Redesigning, adjusting and alterations are required to make a better fit with local conditions."

In addition, the direction of causality (or endogeneity) between corruption and its determining factors presents a limitation that is very difficult to solve (Morales Quiroga, 2009). Corruption is the result of an extremely complex and continuously changing phenomenon that simultaneously involves several institutional, economic, political, cultural, and historical factors. For example, increasing the quantity of subnational governments (i.e., subnational atomization) may be a driver of corruption, particularly in an already relatively corrupt environment such as Venezuela's, but corruption itself can lead to flawed political decentralization and the creation of undemocratic subnational tiers of government, such as community councils. In line with this logic, Holland (1986: 959) argues that causal inference is impossible without making untested assumptions, which basically implies that there can be "no causation without manipulation. ${ }^{10 "}$ 
Future research should address the question, how to link size of population with managerial efficiency, and focus on other settings or, better yet, compare similar cases in different countries following a comparative public administration (CPA) methodology (for a practical guide on CPA research, see Fitzpatrick et al., 2011). Moreover, in future studies it would be particularly useful to collect and analyze longitudinal data on local politicians' incentive structures before and after decentralization reforms, as suggested several years ago by Andersson and van Laerhoven (2007: 1107). 


\section{R E F E R E N C E S L I S T}

Ades, A, \& Di Tella, R. (1997). National champions and corruption: some unpleasant interventionist arithmetic. The Economic Journal, 107(443), 1023-1042.

Ades, A., \& Di Tella, R. (1996). The causes and consequences of corruption. IDS Bulletin, 27(2), 6-10.

Albalate del Sola, D. (2013). The institutional, economic and social determinants of local government transparency. Journal of Economic Policy Reform, 16(1), 90-107.

Andersson, K., \& van Laerhoven, F. (2007). From local strongman to facilitator: Institutional incentives for participatory Municipal governance in Latin America. Comparative Political Studies, 40(9), 1085-1111.

Arshed, N., Carter, S., \& Mason, C. (2014). The ineffectiveness of entrepreneurship policy: Is policy formulation to blame? Small Business Economics, 43(3), 639-659.

Arze, F.J., \& Martínez-Vázquez, J. (2004). Decentralización en América Latina desde una perspectiva de países pequeños: Bolivia, El Salvador, Ecuador y Nicaragua. Gestión y Política Pública, 13(3), 619-661.

Avellaneda, C. N., \& Gomes, R. C. (2015). Is small beautiful? Testing the direct and nonlinear effects of size on municipal performance. Public Administration Review, 75(1), 137-149.

Bardhan, P. (2005). Scarcity, Conflicts, and Cooperation: Essays in Political and Institutional Economics of Development. Cambridge, MA: MIT Press.

Bardhan, P., \& Mookherjee, D. (2006). Accountability and decentralization of infrastructure delivery in developing countries. Economic Journal, 116(1), 101-127.

Beeri, I., \& Navot, D. (2013). Local political corruption: Potential structural malfunctions at the central-local, local-local and intra-local levels. Public Management Review, 15(5), 712-739.

Besley, T., \& Burgess, R. (2002). The political economy of government responsiveness: Theory and evidence from India. Quarterly Journal of Economics, 117(4), 1415-1451.

Boyne, G. A. (2006). Strategies for public service turnaround lessons from the private sector?. Administration \& Society, 38(3), 365-388.

Brennan, G., \& Buchanan, J. (1980). The Power to Tax. New York, NY: Cambridge University Press.

Brunetti, A., \& Weder, B. (2003). A free press is bad news for corruption. Journal of Public Economics, 87(7-8), 1801-1824.

Bryson, J. M., Crosby, B. C., \& Bloomberg, L. (2014). Public value governance: Moving beyond traditional public administration and the New Public Management. Public Administration Review, 74(4), 445-456. 
Burki, S., Perry, G., \& Dillinger, W. (1999). Beyond the Center: Decentralizing the State. Washington, DC: World Bank Press.

Caiden, G., \& Sundaram, P. (2004). The specificity of public service reform. Public Administration and Development, 24(5), 373-383.

Canovan, M. (1999). Trust the people! Populism and the two faces of democracy. Political Studies, 47(1), 2-16.

de Graaf, G., \& Huberts, L. W. (2008). Portraying the nature of corruption using an explorative case study design. Public Administration Review, 68(4), 640-653.

de Mello, L., \& Barenstein, M. (2001). Fiscal decentralization and governance: A cross-country analysis. IMF working paper no. 01-171.

Ellner, Steve, "Hugo Chávez's first decade in office: Breakthroughs and shortcomings." Latin American Perspectives 37.1 (2010): 77-96.

Ellner, Steve, "Venezuela's social-based democratic model: innovations and limitations." Journal of Latin American Studies 43.3 (2011): 421-449.

Enikolopova, R., \& Zhuravskaya, E. (2007). Decentralization and political institutions. Journal of Public Economics, 91(11-12), 2261-2290.

Fan, S., Lin, C., \& Treisman, D. (2009). Political decentralization and corruption: Evidence from around the world. Journal of Public Economics, 93(1-2), 14-34.

Fisman, R., \& Gatti, R. (2002a). Decentralization and corruption: Evidence across countries. Journal of Public Economics, 83(3), 325-345.

Fisman, R., \& Gatti, R. (2002b). Decentralization and corruption: Evidence from U.S. Federal transfer programs. Public Choice, 113(1-2), 25-35.

Fitzpatrick, J., Goggin, M., Heikkila, T., Klingner, D., Machado, J., \& Martell, C. (2011). A new look at comparative public administration: Trends in research and an agenda for the future public administration review, Public Administration Review, 71(6), 821-830.

Gupta, S., Davoodi, H., \& Alonso-Terme, R. (1998). Does corruption affect income inequality and poverty. IMF working paper no. 98-76.

Holden, S.H., Norris, D.F., \& Fletcher, P.D. (2003). Electronic government at the local level: Progress to date and future issues. Public Performance \& Management Review, 26(4), 325-344.

Holland, P.W. (1986). Statistics and causal inference. Journal of the American statistical Association, 81(396), 945-960.

Hood, C. (1991). A public management for all seasons?. Public administration, 69(1), 3-19. Huther, J., \& Shah, A. (1998). Applying a simple measure of good governance to the debate 
on fiscal decentralization. World Bank Policy Research working paper no. 1894.

Inman, R.P., \& Rubinfeld, D.L. (1996). Designing tax policy in federalist economies: an overview. Journal of Public Economics, 60(3), 307-334.

Jonsson, L. (2008). Ideas on organizing Municipalities. Public Management Review, 10(4), 539-558.

Lin, J.Y., \& Nugent, J.B. (1995). Institutions and Economic Development, in Handbook of Economic Development, vol. 3A, ed. J. Behrman and T. N. Srinivasan. Amsterdam, The Netherlands: North-Holland.

Lecuna, A. (2012). Corruption and size decentralization. Journal of Applied Economics, 15(1), 139-168.

Lecuna, A. (2013). From Chavismo to a democratic left in Venezuela. Dissent, 60(3), 26-28.

Mauro, P. (1995). Corruption and growth. Quarterly Journal of Economics, 110(3), 681-712.

McCourt, W. (2008). Public management in developing countries: From downsizing to governance. Public Management Review, 10(4), 467-479.

Morales Quiroga, M. (2009). Corrupción y democracia: América Latina en perspectiva comparada. Gestión y Política Pública, 18(2), 205-252.

Nguyen, T.V., Bach, T.N., Le, T.Q., \& Le, C.Q. (2017). Local governance, corruption, and public service quality: Evidence from a national survey in Vietnam, International Journal of Public Sector Management, 30(2), 137-153.

North, D.C. (1990). Institutions, Institutional Change and Economic Performance. Cambridge, MA: Cambridge University Press.

Oates, W. (1972). Federal Fiscalism. New York, NY: Harcourt Brace and Javonovich.

Panizza, F. (2005). Unarmed utopia revisited: The resurgence of left of centre politics in Latin America." Political Studies, 53(4), 716-734.

Petras, J. (2007). Venezuela: Between ballots and bullets, Global Research, November, 1-14.

Prud'homme, R. (1995). The dangers of decentralization. The World Bank Observer, 10(2), 201-219.

Sanoja, P. (2009). Ideology, institutions and ideas: Explaining political change in Venezuela. Bulletin of Latin American Research, 28(3), 394-410.

Saravia, E., \& Gomes, R.C. (2008). Public Management in South America: What happened in the last ten years?. Public Management Review, 10(4), 493-504.

Seawright, J. (2012). Dismantling Democracy in Venezuela: The Chávez Authoritarian Experiment. By Allan Brewer-Carías. Governance: An International Journal of Policy, Administration, and Institutions, 25(1), 151-164. 
Shleifer, A., \& Vishny, R. (1993). Corruption. Quarterly Journal of Economics, 108(3), 599-617.

Sylvia, Ronald D., and Constantine P. Danopoulos. "The Chávez phenomenon: Political change in Venezuela." Third World Quarterly 24.1 (2003): 63-76.

Tanzi, V. (1998). Corruption around the world: Causes, consequences, scope, and cures. IMF working paper no. 45-4.

Tiebout, C. (1956). A pure theory of local expenditures. The Journal of Political Economy, 64(5), 416-424.

Treisman, D. (2000). The causes of corruption: a cross-national study. Journal of Public Economics, 76(3), 399-457.

Treisman, D. (2002). Decentralization and the quality of government. UCLA working paper.

Webb, E., Cambell, D., Schwartz, R., \& Sechrest, L. (1966). Unobtrusive Measures: Nonreactive Research in the Social Sciences. Chicago, IL: Rand McNally.

Wood, T. (2009) Latin America tamed. New Left Review 58, 135-148. 


\section{A P P E N D I X E S}

TABLE A1.

\section{STATISTICAL SAMPLE}

\begin{tabular}{|c|c|c|c|c|c|c|c|}
\hline \multicolumn{2}{|c|}{ VERY HIGH HUMAN } & \multicolumn{2}{|l|}{ HIGH HUMAN } & \multicolumn{2}{|l|}{ MEDIUM HUMAN } & \multicolumn{2}{|l|}{ LOW HUMAN } \\
\hline DEVELOPMENT & CPI & DEVELOPMENT & $C P I$ & DEVELOPMENT & CPI & DEVELOPMENT & CPI \\
\hline Australia & 8.7 & Albania & 3.2 & Algeria & 2.8 & Afghanistan & 1.3 \\
\hline Belgium & 7.1 & Argentina & 2.9 & Bolivia & 2.7 & Angola & 1.9 \\
\hline Canada & 8.7 & Armenia & 2.7 & Dominican Rep. & 3.0 & Benin & 2.9 \\
\hline Chile & 6.7 & Belarus & 2.4 & El Salvador & 3.4 & Burkina Faso & 3.6 \\
\hline Czech Republic & 4.9 & Bulgaria & 3.8 & Ghana & 3.9 & Burundi & 1.8 \\
\hline Denmark & 9.3 & Colombia & 3.7 & Guatemala & 3.4 & Cameroon & 2.2 \\
\hline Estonia & 6.6 & Costa Rica & 5.3 & Guyana & 2.6 & C. African Re. & 2.0 \\
\hline France & 6.9 & Croatia & 4.1 & Honduras & 2.5 & Chad & 1.6 \\
\hline Germany & 8.0 & Cuba & 4.4 & Iraq & 1.5 & Cote d'Ivoire & 2.1 \\
\hline Greece & 3.8 & Ecuador & 2.2 & Jordan & 5.0 & Eritrea & 2.6 \\
\hline Ireland & 8.0 & Georgia & 4.1 & Kyrgyzstan & 1.9 & Guinea & 1.9 \\
\hline Israel & 6.1 & Kazakhstan & 2.7 & Moldova & 3.3 & Haiti & 1.8 \\
\hline Italy & 4.3 & Kuwait & 4.1 & Morocco & 3.3 & Laos & 2.0 \\
\hline Jamaica & 3.0 & Lebanon & 4.5 & Nicaragua & 2.5 & Liberia & 3.1 \\
\hline Japan & 7.7 & Libya & 2.5 & Paraguay & 2.1 & Mali & 2.8 \\
\hline Lithuania & 4.9 & Malaysia & 4.5 & Sri Lanká & 3.1 & Mauritania & 2.5 \\
\hline Netherlands & 8.9 & Panama & 3.4 & Suriname & 3.7 & Mozambique & 2.5 \\
\hline New Zealand & 9.4 & Peru & 3.7 & Syria & 2.6 & Niger & 2.9 \\
\hline Poland & 5.0 & Romania & 3.8 & Tajikistan & 2.0 & P. N. Guinea & 2.1 \\
\hline Slovakia & 4.5 & Russia & 2.2 & Thailand & 3.4 & Rwanda & 3.3 \\
\hline South Korea & 5.5 & Saudi Arabia & 4.3 & Tunisia & 4.2 & Senegal & 3.0 \\
\hline Spain & 6.1 & Trinidad \& Tob. & 3.6 & Turkey & 4.4 & Sierra Leone & 2.2 \\
\hline United Kingdom & 7.7 & Ukraine & 2.2 & Turkmenistan & 1.8 & Sudan & 1.5 \\
\hline USA & 7.5 & Venezuela & 1.9 & Vietnam & 2.7 & Tanzania & 2.6 \\
\hline & & & & & & Togo & 2.8 \\
\hline & & & & & & Uganda & 2.5 \\
\hline & & & & & & Yemen & \\
\hline & & & & & & Zambia & 3.0 \\
\hline
\end{tabular}

Notes: Countries are subdivided in four categories based on the 2009 Human Development Index (HDI) value by the United Nations Development Programme (UNDP). The Corruption Perception Index (CPI) by Transparency International corresponds to year 2009. 
TABLE A2.

DESCRIPTIVE STATISTICS

\begin{tabular}{|c|c|c|c|c|c|}
\hline VARIABLES & OBSERVATION & MEAN & $\begin{array}{l}\text { STANDARD } \\
\text { DEVIATION }\end{array}$ & MIN. & MAX. \\
\hline Corruption & 100 & 3.81 & 1.98 & 1.30 & 9.40 \\
\hline Democracy & 100 & 5.54 & 2.17 & 1.52 & 9.53 \\
\hline Income & 99 & 11,875 & 12,202 & 400 & 46,381 \\
\hline Education & 98 & .79 & .20 & .27 & .99 \\
\hline Inequality & 98 & 41 & 9 & 24 & 62 \\
\hline Press & 100 & 21 & 25 & 0 & 116 \\
\hline Trade & 97 & 76 & 10 & 50 & 90 \\
\hline Protestant & 100 & $13 \%$ & $18 \%$ & $0 \%$ & $91 \%$ \\
\hline Subnational Atomization & 100 & $1,264,777$ & $1,141,554$ & 52,000 & $6,893,523$ \\
\hline Government Tiers & 100 & 3 & 0.91 & 1 & 4 \\
\hline Revenue Autonomy & 64 & $15 \%$ & $13 \%$ & $.82 \%$ & $52 \%$ \\
\hline Expenditure Autonomy & 64 & $19 \%$ & $15 \%$ & $2.37 \%$ & $59 \%$ \\
\hline
\end{tabular}

TABLE A3.

\section{CORRELATION MATRIX}

\begin{tabular}{lllllllllllll} 
VARIABLES & $(\mathrm{Y} 1)$ & $(\mathrm{X} 1)$ & $(\mathrm{X} 2)$ & $(\mathrm{X} 3)$ & $(\mathrm{X} 4)$ & $(\mathrm{X} 5)$ & $(\mathrm{X} 6)$ & $(\mathrm{X} 7)$ & $(\mathrm{X} 8)$ & $(\mathrm{X} 9)$ & $(\mathrm{X} 10)$ & $(\mathrm{X} 11)$ \\
& & & & & & & & & & & & \\
Corruption (Y1) & 1 & & & & & & & & & & & \\
Democracy (X1) & .73 & 1 & & & & & & & & & & \\
Income (X2) & .85 & .67 & 1 & & & & & & & & & \\
Education (X3) & .54 & .57 & .66 & 1 & & & & & & & & \\
Inequality (X4) & -.44 & -.25 & -.51 & -.44 & 1 & & & & & & \\
Press (X5) & -.48 & -.72 & -.44 & -.19 & .10 & 1 & & & & & \\
Trade (X6) & .51 & .57 & .54 & .57 & -.33 & -.40 & 1 & & & & \\
Protestant (X7) & .39 & .37 & .25 & .07 & .04 & -.35 & .08 & 1 & & & \\
Sub. Atomization (X8) & .48 & .29 & .51 & .18 & -.18 & -.14 & .16 & .24 & 1 & & & \\
Gov. Tiers (X9) & -.02 & .08 & -.02 & -.13 & -.11 & -.10 & -.05 & -.09 & .32 & 1 & & \\
Rev. Autonomy (X10) & .29 & .13 & .34 & .28 & -.24 & -.08 & .19 & .08 & .33 & .16 & 1 & \\
Exp. Autonomy (X11) & .41 & .26 & .48 & .37 & -.33 & -.17 & .26 & .15 & .44 & .19 & .94 & 1 \\
& & & & & & & & & & & & \\
\hline
\end{tabular}


